\title{
Concentration of Manure on Carica Papaya $L$ Growth
}

\author{
Mulono Apriyanto ${ }^{1}$ \\ ${ }^{1}$ Universitas Islam Indragiri, Indonesia \\ Corresponding Author: mulonoapriyanto71@gmail.com
}

Date of Submission: 09-06-2021

Date of Acceptance: 23-06-2021

\begin{abstract}
This study aims to assess growth and production of solo papaya (Carica papaya L., $2 \mathrm{n}=$ 18) in Kabupaten Jember and the effect of giving hormones and formula drum fertilizers. separate plot device, consisting of 2 factors with 3 levels of variation each, was used. Main Factor is a hormone represented by gibberellic acid (GA3) and the synthetic auxin Trichloro acid fenoxi acetate (2-4-5$\mathrm{T})$. The secondary factor is manure which consists of organic manure (OF); organic + mineral fertilizers (FOM) and liquid fertilizers (FL). This test characterized by 9 maintenance $(\mathrm{GA} 3+\mathrm{FO}$, GA3 + FOM (organic and mineral fertilizers), GA + FL (liquid fertilizer); 2-4-5-T + FO, 2-4-5-T + FOM, 2-4-5-T + FL; SH (without hormones) + FO (organic fertilizer); $\mathrm{SH}+\mathrm{FOM}$ and $\mathrm{SH}+\mathrm{FL}$ ). That is done on tropical hydromorphic soil which contains a lot of iron with a strong water surface. Every treatment applied to 3 rows of 4 plants. Judging from the research application, the combination hormone (GA3 + 2-4-5-T) and organic fertilizer + stimulating drum fertilizer formula growth and application of hormones (GA3 and 2-45-T) in papaya trees may reduce planting flowering cycle and early setting of fruit.
\end{abstract}

KEYWORDS: Biomass, flowers, height of plants, number of leaves, planting-flowering

\section{INTRODUCTION}

Agriculture is a big challenge for the development of Downstream Industry. In fact, about $80 \%$ of the population earn a living in there. The majority consists of agriculture vulnerable small family who practice mainly food crops [1]. According to [2]-[4]. Papaya production is 13.7 million tons worldwide and 54,664 tons in Indonesia. From the corner From a nutritional point of view, it must be remembered that consumption of papaya is highly recommended; generally not treated with pesticides. It is classified as one of the fruits best digestible tropics. It can eaten fresh, as a salad or as desserts; or made into juice, syrup, or jam [5], [6].

Papaya is not very energetic because its low sugar content (average $33 \mathrm{kcal}$ versus $55 \mathrm{kcal}$ for fruits other). Thanks to the richness of vitamin $\mathrm{C}$, beta carotene (70\%) and its minerals extraordinary concentration (high level calcium, potassium and magnesium), make a very effective contribution for the defense of the organism, and for fight infection. For a proportion of $100 \mathrm{~g}$ fruit, up to $85 \%$ of the nutritional intake recommended to be ascertained (i.e. $80 \mathrm{mg}$ for adults), which helps meet the body's needs provitamin (A) about 30\% (caribfruits.cirad.fr/fruits_des_antilles/papaye) [7][9]. Despite these various advantages, culture faced with several obstacles in Jember which include yield, choice of fertilization adequate, it's soil mismatch, poor irrigation control, varieties and resistance to disease [3], [10].

Besides, remembering abundance of poultry manure due to expansion of poultry farms on the outskirts Koulikoro, it seems appropriate for us to looking for a drum fertilizer based formula poultry manure is beneficial for papaya production. This is the context of this study, which will try to answer the question the following research: a) do spraying hormones on papaya trees increase growth? b) spraying hormones on tree papaya shortens the cycle? and c) what is the best combination of hormones and a manure formula that can used on papaya? 


\section{EXPERIMENTATION}

A Regulated 5V DC power supply is feed to Arduino board and IC 7805 Voltage regulator. All microcontrollers operate at low voltages and require a small amount of current to operate while solenoids require higher voltages and current. Hence current cannot be supplied to the solenoid from the microcontroller. This is the primary need for IC L293D.A diode(IN4007) and a voltage regulator (7805) IC are connected in the path, the diode is used as a one-way check valve. Since these diodes only allow electrical current to flow in one direction.IC 7805 is a $5 \mathrm{~V}$ Voltage Regulator that restricts the voltage output to $\mathbf{5 V}$ and draws $5 \mathrm{~V}$ regulated power supply. A digital signal generated by Arduino based on the input program is feed to the L293D IC .L293D Is a voltage amplifier that

Hormones are:

(i) Gibberellin acid (GA3): powder, whitish in color and dissolved in alcohol, and;

(ii) 2-4-5-T Trichloro-phenoxy-acetic acid (24-5 -T) crystalline solid is soluble in water.

Fertilizers are:

(i) Urea (46\% nitrogen);

(ii) Potassium sulfate (50\% potassium);

(iii) poultry manure, and;

(iv) Liquid and organic fertilizers (Aton AZ, Turbo root, Codabor, Coda maxi and Boramin $\mathrm{Ca}$ ).

Experimental setup and plot size.

The experiment used was a split plot, with 3 repetitions (Marlina et al., 2020); Hormones are the main factor with 3 levels of variation which one is the main treatment (gibberellic acid (GA3), trichlorophenoxy-acetic acid (2-4-5-T)), and control (hormone free or Not hormone); manure formula is taken as a secondary factor at 3 levels of variation which is a secondary treatment: organic fertilizer formula, fertilizer formula organic + mineral manure, and liquid fertilizer formula. Separated repeats by a $1 \mathrm{~m}$ wide hallway, subdivided into main plot measuring $6 \mathrm{~m} \times 6 \mathrm{~m}$ and plot secondary measuring $6 \mathrm{mx} 2 \mathrm{~m}$. test plot covers an area of 360 $\mathrm{m}^{2}$, length $20 \mathrm{~m}$, and $18 \mathrm{~m}$ wide.

\section{Methods Research}

The experiment was carried out in the gardens of the University of Moch. Sroedji Jember. This area is characterized by ferruginous soil tropical hydromorph with a strong bang aquifer. This soil has a texture like mud, poor in nitrogen and phosphorus, sufficient rich in potassium and slightly acidic. Material Plants Plant materials used consists of seeds of Carica papaya L. (Variety Solo amplifies the $5 \mathrm{~V}$ into $12 \mathrm{~V}$.The L293D IC receives signals from the micro controller and transmits the relative signal to the solenoids .A L293D IC consists of 16 pins in total. 4 ground pins,4-input pins,4-output pins, 2 voltage and enable pins. The digital signal output from 7 pin of arduino is feed to $10^{\text {th }}$ pin of L293D(input),output from $7^{\text {th }}$ pin is feed to $14^{\text {th }}$ pin of L293D(output). The $4^{\text {th }}, 5^{\text {th }}$ and the $13^{\text {th }}, 12^{\text {th }}$ pins of L293D are grounded. L293D has an enable facility which helps you enable the IC output pins. If an enable pin is set to logic high, then state of the inputs match the state of the outputs. If you pull this low, then the outputs will be turned off regardless of the input statesDepending upon our power requirements we can use Transistors/MOSFETs as switches.

8). The seeds of this variety are purchased from resellers Ministry of Agriculture official. In the beginning rainy season, seeds are sown in seeds bed.

Observation and measurement

Observations are made every two months once on two midline plants of each sub-plot and related to plant height measurement $(\mathrm{cm})$, leaf count, leaf biomass dry season, number of flowers, flowering cycle (number of days between planting and interest at $50 \%$ per base plot), the average number and diameter of the fruit. Statistical analysis Results of various observation is the target of analysis of variance using SPSS software version 17.

\section{RESULT AND DISCUSSION}

All measurements made on plants support us draw bar graph their growth or development after processing the data variants. 2 month plant height data analysis after recovery Analysis of data variance revealed no significant difference significant effect of hormones. This show a huge difference significant relationship between the effect of the fertilizer formula and the effect is an interaction between the effects of hormones. Results research shows that plants that receive liquid fertilizer GA3 + earn largest size compared to accept combination formula GA3 + fertilizer organic and mineral manure + fertilizer organic. Combination 2- 4-5-T + fertilizer organic gives plants bigger than it is given 2-4-5-T and fertilizer formula organic + mineral fertilizer. No hormones, the plant has received the fertilizer formula organic + mineral manure obtained the greatest height of the plant that treated with visible liquid fertilizer formula on figure 1.

Analysis of plant height data 4 months after recovery Analysis of variance shows the difference 
significant difference between the effect of hormones and the effect of mineral formulas. It's not detected significant difference between the interaction effects hormones and manure formula.variations shows the results have a very significant effect on the assessment.

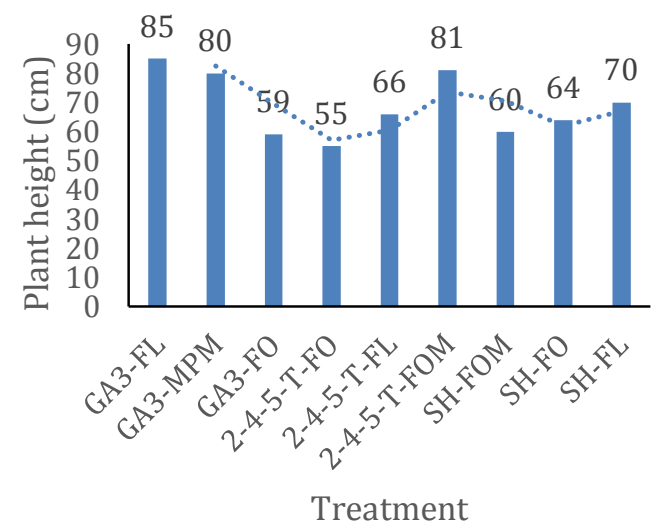

Figure 1. Effect of manure formula and interactions between hormones at high plants 2 months after healing. FOM, Organic Fertilizer + Mineral Fertilizer + Mineral; FO, organic fertilizer; FL, liquid feces; SH, Not Hormone), GA3 (Giberrellic acid), 24-5-T(Trichloro-phenoxy-acetic acid).

Classification according to research results that plants receiving GA3 obtained the largest size while without the largest plant hormone was observed in the plots who received the organic fertilizer formula + mineral manure is presented in figure 2 and figure 3 .

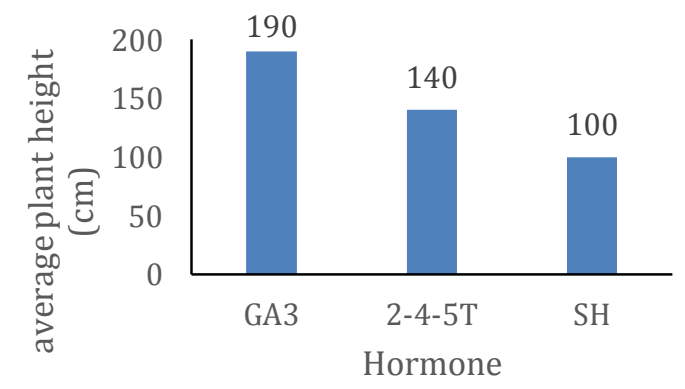

Figure 2. Effect of hormone formula on plant height 4 months after planting

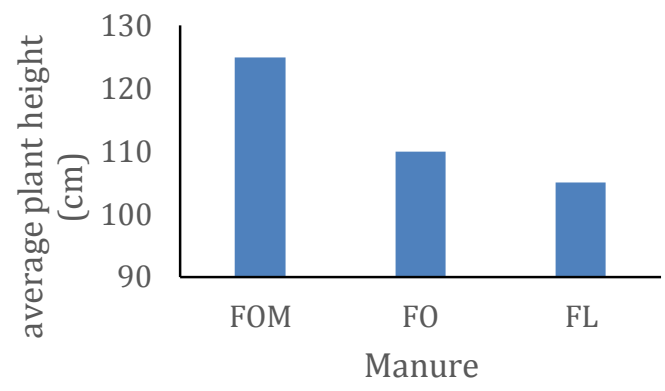

Figure 3. Effect of manure formula on height plant 4 months after planting

Six month plant height data analysis after recovery Analysis of variance reveal not only significant the difference between the effect of the fertilizer formula and people of the interaction between hormones and formula fertilizer, but also the difference not significant between hormone effects.

Classification according to the NewmanKeuls . test make it possible to pay attention plants receiving GA3 and formula organic fertilizer + mineral fertilizer obtained pupuk bigger size in height compared to the combination of GA3 and fertilizer organic; GA3 and liquid dirt formula.

Plants receiving 2-4-5-T and organic manure + fertilizer formula the cage is bigger than the recipient combination of 2-4-5-T and liquid fertilizer formula cage; 2-4-5-T and fertilizer formula organic. Plants without hormones got manure + mineral manure obtain the highest height as opponents receiving organic fertilizers and/or or liquid fertilizer.

Data analysis of the number of leaves 2 months after recovery Analysis of variance of the data obtained no significant difference was found between the effects of the hormone and the formula fertilizer or between the effects of interactions.

Data analysis of the number of leaves 4 months after recovery Analysis of variance in data not found a significant difference between the effects of hormone and fertilizer formula or between effects their interactions. It Needs to be Noticed that plants have the same number leaves whatever the treatment.

Data analysis of the number of leaves 6 months after recovery Analysis of variance in data reveal something very high significant difference between the effects hormones, the effect of the fertilizer formula, and the effect of interactions between hormones and fertilizer formulas. 
The classification, according to Abdoulaye et al., (2020); Apriyanto et al., (2020), created It is possible to pay attention to the plants that receive combination of GA3 and organic fertilizer formula produce more leaves than

plants without hormones and those received GA3 liquid fertilizer.

Two month dry leaf biomass data after recovery Analysis of variance in data, revealing a significant difference between hormonal effects. It worked maybe to detect the very difference significant effect of fertilization formula

and the effect of interactions with hormones. Classification according to Abdoulaye et al., (2020), it is possible to note that the file plants receiving the GA3 +3 combination Liquid formula for manure and GA3 + Organic and Mineral Fertilizer formula gives the amount of dry leaf biomass highest. However, the lowest number was obtained in plants without hormones and those accept GA3+ organic fertilizer formula. Dry leaf biomass data analysis 4 months after recovery Analysis of variance in the data reveal something very high significant difference between the effects hormones and the significant difference between the effect of interaction and fertilization formula.

That's the difference between the effect of the fertilizer formula not statistically significant. Classification, according to the Newman-Keuls test, it is possible to record the largest amount of biomass dry obtained by plants receiving combination formula GA3 + organic fertilizer and formula GA3 + organic manure + mineral manure.

Plants that accept 2-4-5-T combination has the same amount of dry biomass. Without hormones, plants that accept organic manure + mineral manure formula the resulting drier biomass compared to those receiving a combination of GA3 + liquid fertilizer formula and fertilizer organic + mineral impurities; Fertilizer formula hormone free liquid. Dry leaf biomass data analysis 6 month after recovery. Analysis of variance in the data reveals significant difference between effect formula fertilizers and interactions between hormones and fertilizer formulas. It also reveals a very significant difference between hormone effects. That's the classification according to

[9], [11] possible to note the plants that have received the combination formula $2-4-5-\mathrm{T}+$ organic fertilizer + mineral impurities and impurities 2-4-5-T + liquid gives the amount highest dry leaf biomass; they followed by plants that have received a combination of 2-4-5-T + organic fertilizer. Plants that provide biomass lowest dry is obtained from that plot accept other combinations..
Amount of interest

Analysis of variance shows the difference significant difference between the effect of the fertilizer formula and the effects of interactions between hormones and fertilizer formulas. That, also reveals very significant difference between hormone effects. Classification by test NewmanKeuls makes it possible to noted the plant has received 2-4-5-T combination + organic fertilizer formula + mineral manure and fertilizer manure 2-45 - $\mathrm{T}+$ liquid fertilizer provides the greatest number of flowers ; they followed in descending order by plants accept a combination of 2-4-5-T + fertilizer organic, GA3+ organic and mineral fertilizers, GA3 + organic fertilizer, GA3 + fertilizer manure and $245 \mathrm{~T}+$ liquid fertilizer. Plant with the least amount of interest obtained from plots that do not accept. Analysis of variance shows the difference which is very significant only between effects hormone. The significance of the data shows that hormone contribution file reduces vegetation plant cycle independently of formula fertilization. hormones.

Number and diameter of fruit

We recorded fruit formation on plants that have received hormones GA3 + organic fertilizer + mineral fertilizer cage and 2-4-5-T + organic fertilizer + mineral fertilizer. Plants that receive AG3 seems to produce more fruit compared to those receiving 2-4-5-T (26 versus 19$)$.

Plants that receive AG3 appears to produce larger diameter fruit than the obtained at 2-4-5-T $(4.2 \mathrm{~cm}$ versus $3.2 \mathrm{~cm})$. The results obtained from this experiment shows that plants that accept GA3 + organic fertilizer formula cage + mineral fertilizer and accept 2-4-5-T + organic fertilizer formula + mineral manure has largest pruning, amount of biomass highest dry, highest number of flowers, shortest planting-flowering cycle and early fruit production. Our results strengthen with studies conducted on the behavior of legumes, Phaseolus vulgaris [12], under the influence of growth hormone: auxin and gibberellic acid.

Growth hormone has an effect on faster plant growth produce some seedless fruit other applications [13], [14]. Plants under the influence they are disproportionate and very big extreme because hormones work especially in roots, stems and leaf reproduction. However, for observing this phenomenon, it was necessary to grow enough plants to

experiment to be statistically valid. In addition, the growth period must be

long enough to see the main difference and all plants must absorb the amount sufficient hormones [3], [15]. According to the hypothesis, 
plants treated with auxin concentration 1 x $10-4$ $\mathrm{mol} / \mathrm{L}$, and it is treated with gibberellic acid with a

\section{CONCLUSION}

From the results obtained, the diameter larger plants are obtained in level plots that receive organic fertilizer formula + manure and organic manure [4]. Plants that accept GA3 + organic fertilizer formula + highest yield of mineral fertilizers number of leaves compared to those who received other combinations of GA3 2-4-5-T which are not stimulate leaf production in the factory. Without hormones, plants that get formula organic fertilizer has the number of leaves more than those who received organic fertilizer + mineral fertilizer and fertilizer liquid. The largest amount of dry biomass is obtained by PT plants receiving the combination

2-4-5-T + organic fertilizer + fertilizer formulation mineral cages and 2-Formulation of fertilizers cage 4-5-T+. Lowest dry quantity biomass provided by plants that receive a combination of organic fertilizer formula GA3+ and GA3+ liquid dirt formulas. The addition of hormones reduces the cycle plant vegetation regardless of formula fertilization. Fruit formation is obtained on plants receiving fertilizer organic hormone GA3++ + manure minerals and 2-4-5-T + organic fertilizer + mineral impurities. Plants that receive GA3 seems to produce more fruit than those receiving 2-4-5-T (26 versus 19). Plants receiving GA3 seems to provide fruit diameter greater than that obtained by $2-4-5-\mathrm{T}(4.2 \mathrm{~cm}$ versus $3.2 \mathrm{~cm}$ ).

\section{REFERENCES}

[1] Tedi Susilo; and M. Apriyanto, "Pengaruh Dua Hormon Pertumbuhan Dan Tiga Pupuk Kendang Formula Pada Varietas Papaya (Carica Papaya L.) Di Simpang Kiri, Kecamatan Pelangiran," J. Agro Indragiri, vol. 5, no. 1, pp. 6-11, 2020, doi: 10.32520/jai.v5i1.1451.

[2] S. Heryani and R. F. Silitonga, "Penggunaan Tepung Sagu (Metroxylon sp.) asal Riau Sebagai Bahan Baku Kukis Cokelat," War. Ind. Has. Pertan., vol. 34, no. 2, p. 53, 2018, doi: 10.32765/wartaihp.v34i2.3591.

[3] M. Apriyanto, Partini, H. Mardesci, G. Syahrantau, and Yulianti, "The Role of Farmers Readiness in the Sustainable Palm Oil Industry The Role of Farmers Readiness in t he Sustainable Palm Oil Industry," $J$. Phys. Conf. Ser., vol. 1764, no. 1, p. 012211, 2021, concentration of $500 \mathrm{ppm}$ has more growth fast 6596/1764/1/012211.

[4] Y. Riono and M. Apriyanto, "PEMANFAATAN ABU SEKAM PADI DALAM INOVASI PEMUPUKAN KACANG HIJAU (Vigna radiate L) DI LAHAN GAMBUT," Selodang Mayang J. Ilm. Badan Perenc. Pembang. Drh. Kabupaten Indragiri Hilir, vol. 6, no. 2, p. 60, 2020, doi: 10.47521/selodangmayang.v6i2.164.

[5] M. Apriyanto and Yulianti, "Evaluasi Sensori Produk Coklat Batangan Berbahan Baku Biji Kokao Kering Pada Berbagai Perlakuan Fermentasi," J. Teknol. Pertan., vol. 9, no. 2, pp. 53-59, 2020.

[6] M. Apriyanto, L. Fangohoi, and D. F. Diba, "Water Sources on Organoleptics and Characteristics of Sago Flour," Merit Res. J. Food Sci. Technol., vol. 6, no. 1, pp. 1-7, 2021, doi: 10.5281/zenodo.4586823.

[7] M. Arpah, Marlina, and M. Apriyanto, "Effect Of Grant Palm Oil Ash To The Growth And Production Of Two Corn Varieties (Zea Mays L) In Peatland," Int. J. Sci. Technol. Res, vol. 9, no. 4, pp. 990-993, 2020.

[8] H. Mardesci, S. Santosa, N. Nazir, and R. A. Hadiguna, "Penentuan Produk Prospektif Dari Tiga Produk Unggulan Olahan Kelapa Di Kabupaten Indragiri Hilir, Riau," J. Teknol. Pertan., vol. 6, no. 2, pp. 11-18, 2017, doi: 10.32520/jtp.v6i2.103.

[9] Marlina, I. Sari, E. Y. Yusuf, Y. Riono, and M. Apriyanto, "Utilization Of Industrial Waste Pulp And Palm Oil On Growth And Results Of Corn (Zea Mays L) On Peat," Int. J. Sci. Technol. Res, vol. 9, no. 1, pp. 109112, 2020.

[10] M. Apriyanto and Yulianti, "Analisis Produksi dan Pemasaran Gula Merah di Desa Rumbai Jaya, Kecamatan Kempas, Kabupaten Indragiri Hilir," J. Teknol. Pertan., vol. 9, no. 1, pp. 26-29, 2020.

[11] S. Abdoulaye, T. B. Mamourou, and Y. Tassiou, "Effects of two growth hormones and three manure formulas on a variety of papaya ( Carica papaya L .) in the SudanoSahelian zone of Mali," African J. Agric. Res., vol. 16, no. 12, pp. 1631-1639, 2020, doi: 10.5897/AJAR2020.15071.

[12] D. S. Buss, G. B. Dias, M. P. Santos, J. A. Ventura, P. Machado, and B. Fernandes, "Oxidative Stress Defence Response of Carica papaya Challenged by Nitric Oxide , Papaya 
meleira virus and Saccharomyces cerevisiae," pp. 55-64, 2011.

[13] M. Apriyanto and R. Rujiah, "Penurunan total polifenol, etanol, asam laktat, asam asetat, dan asam amino selama fermentasi biji kakao asalan dengan penambahan inokulum," J. Gizi dan Diet. Indones. (Indonesian J. Nutr. Diet., vol. 5, no. 1, pp. 1-8, 2018, doi: 10.21927/ijnd.2017.5(1).1-8.

[14] M. Apriyanto, "Analysis of Amino Acids in Cocoa Beans Produced during Fermentation by High Performence Liquid Chromatography (HPLC)," Int. J. Food Ferment. Technol., vol. 7, no. 1, pp. 25-31, 2017.

[15] M. Apriyanto and R. Rujiah, "Pengaruh Perendaman Larutan Sulfit Dan Pengasapan Belerang Terhadap Mutu Kopra Putih Di Kabupaten Indragiri Hilir," J. Teknol. Pertan., vol. 8, no. 2, pp. 91-96, 2019, doi: 10.32520/jtp.v8i2.941. 